\title{
1970).
}

Bulls were high-quality Shorthorns or

\section{Returns from Southern Forest Grazing}

\section{H. A. PEARSON AND L. B. WHITAKER}

Highlight: Over a 10-year span, commercial herds grazing bluestem forest ranges in central Louisiana provided data on the returns from good cattle and range management. With labor cost excluded, per-cow returns on the investment were from 14 to $18 \%$, with the best return from light stocking. Returns per acre of range varied from $\$ 1.88$ under light stocking to $\$ 2.67$ under heavy use.

For perhaps 10 years after pine regeneration becomes established, forests in the southern Coastal Plain contain substantial volumes of forage. Bluestem grasses (Andropogon spp.) are the chief component, but a large variety of forbs and other grasses contribute. Nutritional values are good in spring and early summer; and if the cattle receive supplemental feed at other seasons, they can be kept on the range all year.

Large numbers of cattle are grazed on this forage-usually in small herds and at a low level of management (Fig. 1). The majority of cattlemen do not own enough land to support a herd of profitable size, and therefore must arrange for additional grazing on neighboring timbered tracts. Many forest owners grant grazing rights free of charge, and some assess a small fee to be paid either in cash or by the construction of fences or other improvements.

Research has shown that pines, even those in seedling stages, are not seriously damaged when grazing is properly managed (Pearson et al., 1971). Some practices serve both cattle and timber interests. For example, prescribed burning is useful in manipulating forage utilization by cattle and also aids in controlling undesirable hardwoods, reducing hazard from wildfire, and preparing seedbeds for pine (Halls et al., 1964).

This paper reports costs and returns from a reasonably high level of herd and range management. The data are from three privately owned herds that grazed from 1961 through 1971 on the Palustris Experimental Forest in central Louisiana.

The authors are principal range scientist and range technician, Southern Forest Experiment Station, Forest Service, U. S. Department of Agriculture at Pineville, Louisiana.

Manuscript received March 2, 1972.
Grazing returns per acre varied from $\$ 1.82$ to $\$ 2.67$ annually. To the cattle owner, these values should be an inducement to improve his management practices. To the manager of forest land, they suggest that the forage may be a source of income while the pines are growing to sizes at which they can be marketed.

While some southern range cattle are maintained in part on improved pasture, the present herds were typical of many others in that they had recourse only to native forage.

\section{Herd and Range Management}

Most cows were Brahman crossbreeds, which appear to be the most efficient producers on southern forest range (Duvall and Halls, 1963; Whitaker et al.,
Herefords which were replaced when their breeding efficiency declined, generally about age 9. The breeding season was limited to late winter and spring. Calves dropped from late November through February are old enough to utilize all the milk the cows produce when the native grasses begin to grow in the spring. Calves were marketed in August to permit cows to regain thrift before winter.

The cattle were sprayed or dusted three or four times annually for control of external parasites. Calves were vaccinated for blackleg, and bull calves were castrated at no later than 3 months of age.

The ranges were on areas from which the old-growth longleaf pine had been cut some years previously and which were planted or seeded to slash pine (Pinus elliottii var. elliottii) over the period of the study. Areas to be regenerated were prescribe-burned in the year before pines were established. They were then protected from fire until the trees were 5 to 6 years old, after which they were burned on a 3-year rotation. Grazing was heaviest on newly burned areas, because fires remove dead plant material and stimulate new growth that is high in protein (Campbell et al., 1954). Thus rotational burns served in lieu of temporary fencing to control cattle distribution over the range.

Herbage yields throughout the study averaged nearly 2,000 $\mathrm{lb}$./acre annually. Three stocking rates were tested: 26,20 , and 13 acres per cow. These rates were considered to represent light, moderate,

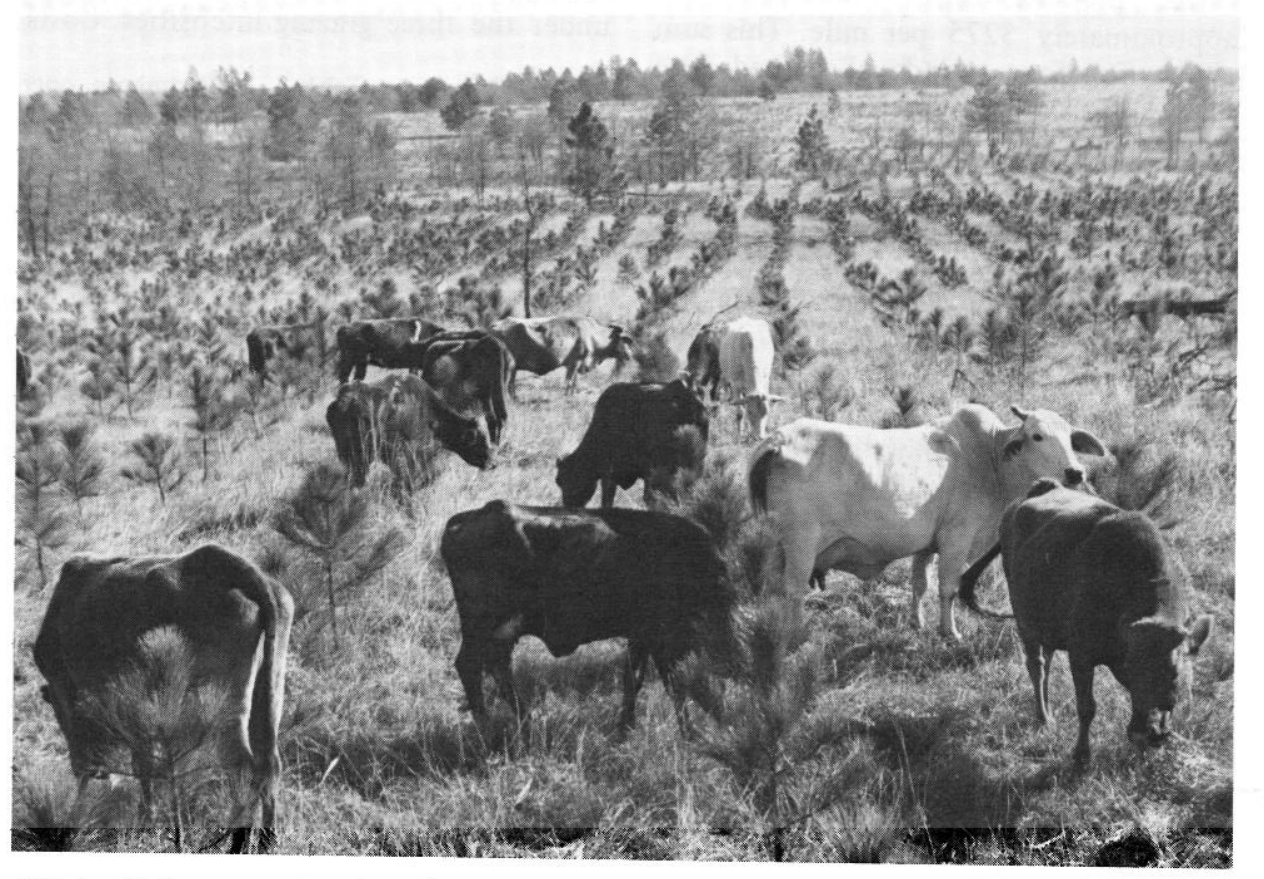

Fig. 1. Brahman crossbreed cattle grazing a 2-year-old slash pine plantation in central Louisiana. 
and heavy grazing. Utilization averaged 35,49 , and $57 \%$. Each herd was assigned to one range and to one grazing intensity throughout the decade of study. Although yearly fluctuations occurred, neither grazing intensity nor pine growth reduced herbage yields sufficiently to necessitate reductions in cattle numbers.

Since range forage is notably deficient in nutrients after the growing season ends, about $400 \mathrm{lb}$. of cottonseed cake (41\% crude protein) was fed each cow during late fall, winter, and early spring (Duvall, 1969; Pearson and Whitaker, 1972). About $260 \mathrm{lb}$. of grass hay per cow was fed in late winter or on cold, rainy days. Steamed bonemeal and salt were provided free-choice all year; intakes averaged 17 and $21 \mathrm{lb}$, respectively.

\section{Costs and Returns from Cattle}

As land costs are logically charged to timber interests, this presentation considers mainly the direct expenses for grazing. These are designated investment and operational costs. Investments include fences, water supplies, corrals, animals, equipment, and supplies. Operational costs include such items as feed, rotation burning, and care of bulls.

The three ranges differed somewhat in size but approximated a section each. Since range area was fixed, herd size varied with stocking rate. All values given here have been adjusted for herds of a size to graze 640 acres at the specified intensities of use. Some costs varied with herd size and others were largely independent.

\section{Investment Costs}

At present, fence materials cost approximately $\$ 275$ per mile. This sum allows for four strands of barbed wire with posts 40 feet apart and wire stays between all posts. Labor and equipment to build the fence cost approximately $\$ 150$. If $\$ 25$ is added for unexpected expenses, the total per mile is $\$ 450$. Four miles of perimeter fence (enclosing one section) cost about $\$ 1,800$ or $\$ 72, \$ 56$, and $\$ 37$ per cow for light, moderate, and heavy grazing (Table 1 ).

Since the ranges initially included no watering facilities, ponds were installed at an approximate cost of $\$ 350$ each, or $\$ 14, \$ 11$, and $\$ 8$ per cow for light, moderate, and heavy use. Treated-board corrals, 6 feet high and with two or more working pens to handle a one- or two-bull herd, cost $\$ 350$.

Though many of the cattle had been purchased for less, a value of $\$ 130$ per head is realistic on today's market. Bulls cost about $\$ 450$ apiece and served 25 to 30 cows, or $\$ 18$ per cow regardless of grazing intensity.

Other investment expenses included feed troughs, storage sheds, veterinary supplies, and a vchicle charge. These outlays were estimated to be $\$ 23, \$ 19$, and $\$ 15$ per cow for light, moderate, and heavy grazing intensities.

Depreciation on the initial investment (including replacement of fence posts and wire) was considered as maintenance and included under operational expenses.

\section{Operational Costs}

In forest grazing, much of the labor is part time; occasionally several men are needed, but on many days no work is required. Off-season and sparetime labor can be used efficiently. On the average, one man-month of labor is sufficient to maintain 25 cows for a year (Halls and Duvall, 1961). The operating expense of labor is not included in our tabulation but would vary with size of the herd. In 1961 Halls and Duvall estimated annual labor costs for a 25 -cow herd at $\$ 13$ per cow. On the Texas Experimental Ranch, estimated labor cost per cow was \$11.25 (Kothmann et al., 1970)

Range supplements were the biggest operating expense, averaging $\$ 20.67$ per cow annually, regardless of grazing intensity (Table 1).

Grazing fees ( $\$ 1.20$ per cow year) are omitted from the table, since they were not based on actual forage value.

Prescribed burning was considered to cost $\$ 0.99$ per acre (Yoho et al., 1969). Since about half the expense was chargeable to tree growing, costs per cow approximated $\$ 3.47, \$ 2.48$, and $\$ 1.49$ under the three grazing intensities. Costs of two forage surveys each year were estimated at $\$ 25$ per survey or $\$ 2, \$ 1.67$, and $\$ 1.14$ per cow.

A special pasture and additional supplemental feed were necessary for the bulls during nonbreeding periods. Costs to maintain and replace bulls approximated $\$ 4$ per cow. Cows generally produce for 10 to 12 years. The difference between the selling price of a cow and the cost of her replacement was about $\$ 20$, or $\$ 2$ per cow when prorated over 10 years.

Miscellaneous operating costs included death losses, vehicle operation, taxes, and upkeep of fences, corrals, troughs, and equipment. The total for these items was $\$ 8.25$ per cow.

\section{Returns}

Calf crops averaged 82,73 , and $70 \%$ with light, moderate, and heavy grazing. Corresponding 10-year average calf weights were 444,419 , and $421 \mathrm{lb}$. at 7 months. Gross annual returns per cow averaged $\$ 89.35$ for light grazing, $\$ 74.57$ for moderate grazing, and $\$ 72.20$ per cow for heavy grazing (Table 1). The lower calf crops at the higher stocking rates probably reflected forage intakes. That is, the animals were evidently forced to eat less palatable and less nutritious forage.

Subtracting the operating expenses from the gross annual returns leaves $\$ 48.96$ per cow for light grazing, $\$ 35.50$ for moderate grazing, and $\$ 34.65$ for heavy grazing-or 18,14, and $16 \%$ net return on the initial investments, respectively. If the cost of labor is included in the operating expenses, an additional $\$ 13$ per cow would be subtracted from the

Table 1. Investments, operating costs, and returns (dolars) per cow for cattle grazing forest range.

\begin{tabular}{lrrr}
\hline \hline & \multicolumn{3}{c}{ Grazing intensity } \\
\cline { 3 - 4 } Item & Light & Moderate & Heavy \\
\hline Investment & & & \\
Fencing & 72.00 & 56.00 & 37.00 \\
Water facilities & 14.00 & 11.00 & 8.00 \\
Corrals & 14.00 & 11.00 & 8.00 \\
Cow & 130.00 & 130.00 & 130.00 \\
Bull & 18.00 & 18.00 & 18.00 \\
Miscellaneous & 23.00 & 19.00 & 15.00 \\
Total & 271.00 & 245.00 & 216.00 \\
Operation (per year) & & & \\
Feed & 20.67 & 20.67 & 20.67 \\
Range burning & 3.47 & 2.48 & 1.49 \\
Forage survey & 2.00 & 1.67 & 1.14 \\
Care of bull & 4.00 & 4.00 & 4.00 \\
Cow replacement & 2.00 & 2.00 & 2.00 \\
Miscellaneous & 8.25 & 8.25 & 8.25 \\
Total & 40.39 & 39.07 & 37.55 \\
Returns (per year) & & & \\
Gross & 89.35 & 74.57 & 72.20 \\
Net & 48.96 & 35.50 & 34.65 \\
\hline
\end{tabular}


net return for light grazing, $\$ 11$ for moderate grazing, and $\$ 9$ for heavy grazing. Including labor, the returns on investment are 13,10 , and $12 \%$, respectively.

\section{Discussion}

If the expense of labor is included, returns on the investment were 13,10 , and $12 \%$ for light, moderate, and heavy grazing. Still greater returns are possible. Certain per-head costs decrease in larger operations. For example, a storage shed serving 25 cows costs about $\$ 300$, while a shed for twice this number would cost only $\$ 400$. Labor costs can be lowered by increasing herd size and perhaps by use of liquid and range-block supplements.

If labor charges are excluded, net returns per acre of range were $\$ 1.88$, $\$ 1.82$, and $\$ 2.67$ for the three grazing intensities. These values may be of interest to the landowner who is considering the lease of grazing rights. While leases are always a matter of negotiation in the light of local conditions, a fee equal to $10 \%$ of net returns per acre may not be unreasonable when herd and range are carefully managed.

The ranges in this study were almost fully productive throughout the decade. Now the tree crowns are beginning to close on some portions, and forage growth will diminish. Some increase will occur when the trees are thinned, perhaps at ages 15 to 18 years; but until the stands are harvested, forage will average perhaps half the present rate of $2,000 \mathrm{lb}$./acre. Consequently, cattle numbers must be decreased or additional acreage provided. Per-acre returns from cattle will decline accordingly.

Still under the proviso of careful management, heavy grazing yields highest returns per acre of range and does not damage timber unduly. For reasons not entirely clear, the heavy-grazing herd in the present study had the poorest calf crops and lighter calves at market time. Perhaps increased supplementation or rearrangement of the feeding schedule would have increased beef production.

\section{Literature Cited}

Campbell, R. S., E. A. Epps, Jr., C. C. Moreland, J. L. Farr, and F. Bonner, 1954. Nutritive values of native plants on forest range in central Louisiana. La. Agr. Exp. Sta. Bull. 488, 18 p.
Duvall, V. L. 1969. Comparison of supplementation methods for cow herds grazing pine-bluestem range. J. Range Manage. 22:182-187.

Duvall, V. L., and L. K. Halls. 1963. Outlook for beef cattle on southern forest ranges. In Soc. Amer. Forest. Proc. 1962:76-79.

Halls, L. K., and V. L. Duvall. 1961. Profits and cost of forest grazing. Forest Farmer 20(7):151-152.

Halls, L. K., R. H. Hughes, R. S. Rummell, and B. L. Southwell. 1964. Forage and cattle management in longleaf-slash pine forests. U. S. Dep. Agr. Farmers' Bull. 2199, 25 p.

Kothmann, M. M., G. W. Mathis, P. T. Marion, and W. J. Waldrip. 1970. Livestock production and economic returns from grazing treatments on the Texas Experimental Range. Tex. Agr. Exp. Sta. Bull. B-1100, 39 p.

Pearson, H. A., L. B. Whitaker, and V. L. Duvall. 1971. Slash pine regeneration under regulated grazing. J. Forest. 69:744-746.

Pearson, H. A., and L. B. Whitaker. 1972. Thrice-weekly supplementation adequate for cows on pine-bluestem range. J. Range Manage. 25:315-316.

Whitaker, L. B., H. A. Pearson, and W. M Monroe. 1970. Crossbred cattle-custombuilt for piney woods range. La. Cattleman 70(9):8-9.

Yoho, J. G., G. F. Dutrow, and J. E. Moak. 1969. What it costs to practice forestry Forest Farmer 28(11):20-24, 26, 28, 30-31. 